\title{
PENGARUH GOOD CORPORATE GOVERNANCE TERHADAP EFISIENSI BANK SYARIAH TAHUN 2012-2016 DENGAN KINERJA SOSIAL SEBAGAI VARIABEL INTERVENING
}

\author{
Abdul Ghofur \\ Program Studi Ekonomi Islam, Fakultas Ekonomi dan Bisnis \\ Univesitas Airlangga \\ Email: abdul-ghofur-feb14@feb.unair.ac.id \\ Puji Sucia Sukmaningrum \\ Program Studi Ekonomi Islam, Fakultas Ekonomi dan Bisnis \\ Universitas Airlangga \\ Email: puji.sucia@feb.unair.ac.id
}

\section{ARTICLE HISTORY}

Received:

12 Oktober 2018

Accepted:

1 November 2018

Online available:

2 November 2018

\section{Keywords:}

Good Corporate

Governance, Social

Performance, Efficiency, Islamic Banks

\begin{abstract}
This study aims to determine the effect of Good Corporate Governance and social performance on efficiency in Bank Syariah Period 2012-2016. The sample in this study used a purposive sampling method of Islamic Commercial Banks (BUS) in Indonesia, from 13 BUS took 6 BUS that met the sample criteria to be tested. Furthermore, this research uses path analysis, while the research approach used is quantitative approach using analysis technique PLS (Partial Least Square). In this research, there are three latent variables namely Good Corporate Governance as an exogenous or independent variable, social performance as endogen intervention variable, and efficiency as an endogen variable. The indicators used to reflect the Good Corporate Governance Variables are the Board of Commissioners (DK), the Composition of Independent Commissioners (KDKI), the Sharia Supervisory Board (DPS), the Frequency of Sharia Supervisory Board Meetings (FRDPS), and the Frequency of Audit Committee Meetings (FRKA). The indicators used to reflect social performance are financing MudharabahMusyarakah, Zakat, and Qard.. Furthermore, the efficiency indicator is reflected by the ratio of BOPO (Operational Cost to Operating Income). The results of this study indicate that GCG has a significant positive effect on efficiency, GCG has a significant positive effect on social performance, social performance has a significant negative effect on efficiency, GCG has a significant negative effect on efficiency through social performance.
\end{abstract}




\begin{abstract}
ABSTRAK
Kata Kunci:

Tujuan dari penelitian ini adalah untuk mengetahui pengaruh tata Good Corporate Governance, Kinerja Sosial, Efisiensi, Bank Syari'ah kelola perusahaan yang baik dan kinerja sektor sosial terhadap efisiensi bank syari'ah periode 2012-2016. Cara pengambilan data menggunakan purposive sampling dari Bank Umum Syari'ah (BUS) di Indonesia sebanyak 6 BUS dari total 13 yang sesuai dengan kriteria penelitian ini. Penelitian ini menggunakan analisis path dan pendekatan kuantitatif dengan metode Partial Least Square (PLS). Penelitian ini memiliki tiga variabel laten, yaitu Good Corporate Governance sebagai variabel independen atau endogen, kinerja bidang sosial sebagai variabel intervensi endogen, dan efisiensi sebagai variabel endogen. Indikator-indikator yang digunakan untuk mendiskripsikan Good Corporate Governance di antaranya adalah Dewan Komisaris (DK), Komisi Dewan Komisaris Independed (KDKI), Dewan Pengawas Syari'ah (DPS), Frekuensi Rapat Dewan Pengawas Syari'ah (FRDOS), dan Frekuensi Rapat Komite Audit (FRKA). Sedangkan indikator untuk merefleksikan kinerja sosial adalah pembiayaan Mudharabah-Musyarakah, zakat, dan Qard. Indikator efisiensi dapat dilihat dari rasio biaya operasional terhadap pendapatan operasional (BOPO). Hasil studi ini menemukan bahwa GCG memiliki pengaruh positif yang signifikan terhadap efisiensi, GCG memiliki pengaruh positif yang signifikan juga dengan kinerja bidang sosial, namun kinerja sosial justru memiliki pengaruh yang negatif terhadap efisiensi. Di samping itu, GCG memiliki pengaruh negatif yang signifikan melalui kinerja sosial.
\end{abstract}

\title{
PENDAHULUAN
}

Bank syariah meupakan bentuk dari penerapan sistem ekonomi syariah Islam yang merupakan bagian dari nilai-nilai ajaran Islam yang mengatur dalam hal perekonomian umat dan tidak bisa terpisahkan dari aspek-aspek lain dari ajaran Islam yang komprehensif dan universal. Komprehensif artinya ajara Islam mencakup seluruh aspek kehidupan. Universal berarti bahwa syariah Islam dapat diterapkan pada seluruh aspek kehidupan tanpa memandang waktu, ras, suku, golongan, dan agama sesuai dengan prinsip Islam sebagai agama yang "rahmatan lil alamin", Menurut Jafri Khalil (2002), ada empat prinsip utama yang selalu mendasari jaringan kerja perbankan dengan sistem syariah, yaitu: (1)perbankan non riba, (2 )perniagaan halal dan tidak haram, (3 
keridhaan piak-piak dalam berkontrak, (4)pengurusan dana yang amanah, jujur dan bertanggung jawab.

Untuk meredam krisis tersebut, pemerintah mengeluarkan kebijakan Blanket Guarantee yaitu memberikan jaminan atas seluruhsimpanan masyarakat, termasuk kewajiban pembayaran bankoleh Badan Penyehatan Perbankan Nasional bekerjasama dengan Kementerian Keuangan melalui Unit Pelaksana Penjaminan Pemerintah (LPS, 2018).

Bank Syariah di Indonesia terdiri dari tiga jenis bank, yaitu Bank Umum Syariah (BUS), unit Unit Usaha Syariah (UUS), dan Bank Pengkreditan Rakyat Syariah (BPRS). Perkembangan perbankan di Indonesia mengalami peningkatan yang cukup pesat dalam beberapa tahun terakhir, hal tersebut dapat dilihat dari data pertumbuhan jumlah Bank syariah setiap tahunnya yang cenderung meningkat.

Tabel 1

Perkembangan Perbankan Syariah di Indonesia

Periode 2010-2016

(dalam satuan unit)

\begin{tabular}{|c|c|c|c|c|c|c|c|c|}
\hline Indikator & 2010 & 2011 & 2012 & 2013 & 2014 & 2015 & 2016 & 2017 \\
\hline \multicolumn{9}{|l|}{ Bank Umum Syari'ah } \\
\hline - Jumlah Bank & 11 & 11 & 11 & 11 & 12 & 12 & 13 & 13 \\
\hline - Jumlah Kantor & 1215 & 1410 & 1745 & 1998 & 2163 & 1990 & 1896 & 1825 \\
\hline \multicolumn{9}{|l|}{ Unit Usaha Syari'ah } \\
\hline $\begin{array}{ll}\text { - } & \text { Jumlah Bank Umum } \\
\text { Konven yang memiliki } \\
\text { UUS } \\
\text { - } \quad \text { Jumlah Kantor }\end{array}$ & 23 & 24 & 24 & 23 & 22 & 22 & 21 & 21 \\
\hline Bank Pembiayaan Rakyat & 262 & 336 & 517 & 590 & 320 & 311 & 332 & 344 \\
\hline Syari'ah & 150 & 155 & 158 & 163 & 163 & 163 & 166 & 167 \\
\hline $\begin{array}{ll}\text { - } & \text { Jumlah Bank } \\
\text { - } & \text { Jumlah Kantor }\end{array}$ & 286 & 364 & 401 & 402 & 439 & 446 & 453 & 441 \\
\hline Total Kantor & 1763 & 2101 & 2663 & 2990 & 3119 & 2944 & 2881 & 2811 \\
\hline
\end{tabular}

Sumber: Statistik Perbankan Syariah (SPS), 2010-2017 (data diolah)

Berdasarkan informasi dari table 1.1 diatas, perkembangan BUS mengalami peningkatan yang cukup pesat dalam periode 2010-2014, hal tersebut mengindikasikan semakin berkembangnya BUS dikalangan masyarakat. Akan tetapi pada tahun 2015-2017 terjadi tren penurunan dari jumlah BUS, hal tersebut terjadi karena Otoritas Jasa Keuangan (OJK) mengisaratkan kepada lembaga perbankan untuk lebih meningkatkan 
efisiensi perusahaan, yang kemudian hal tersebut direspon oleh beberapa bank syariah dengan cara mengurangi jumlah kantor cabangnya.

Efisiensi menjadi tugas dari bank syariah yang masih belum bisa diatasi hingga saat ini. Tingkat efisiensi perbankan syariah masih tertinggal jika dibandingkan dengan perbankan konvensional bila dilihat dari rasio biaya operasional terhadap pendapatan operasionalnya (BOPO), hal tersebut dapat dilihat dari statistik tingkat rasio BOPO perbankan Syariah yang dikeluarkan oleh Otoritas Jasa Keuangan (OJK) sejak 2010-2017.

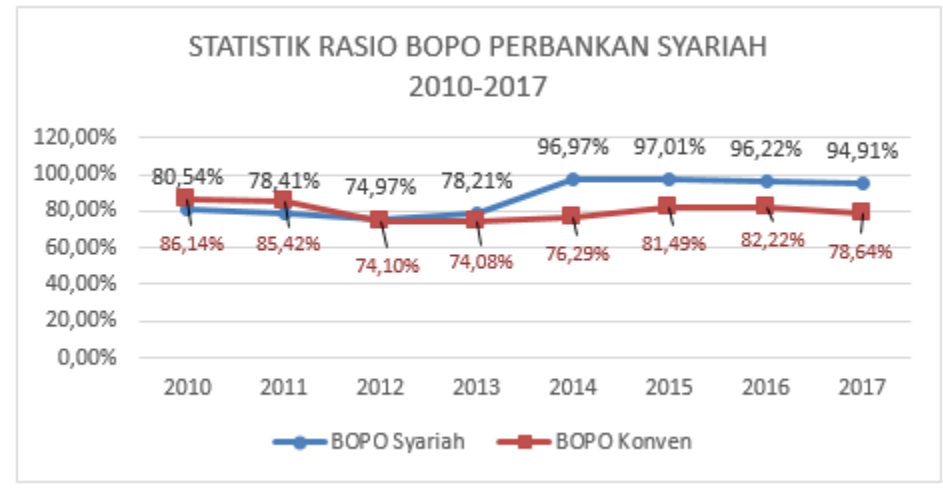

Sumber: Statistik Perbankan Syariah (SPS) 2010-2017 (data diolah)

Gambar 1

Perkembangan Rasio BOPO Perbankan Syariah

2010-2017

Berdasarkan informasi dari grafik di atas dapat dilihat bahwa, rasio BOPO perbankan syariah masih tergolong cukup tinggi menyentuh angka 94,91\% per Desember 2017, tentunya angka tersebut jauh dari angka ideal yang harusnya berada pada angka $70 \%$ 80\% (Karyadi dalam Arifn 2009), bandingkan dengan tingkat efisiensi perbankan konvensional yang berada pada angka 78,64\% per Desember 2017. Menurut Direktur Utama BCA Syariah John Kosasih, salah satu penyebab masih tingginya rasio BOPO perbankan Syariah dikarenakan industri perbankan Syariah yang tergolong masih baru jika dibandingkan dengan konvensional sehingga belum mencapai skala ekonomisnya. Oleh sebab itu perlu adanya upaya dalam meningkatkan efisiensi perbankan Syariah agar dapat menjaga kelangsungan tugas dan fungsi perbankan syariah dimasa yang akan datang.

Antonio (2001:201) mengatakan bahwa terdapat beberapa fungsi bank syariah, yaitu pertama sebagai manajer investasi yang bertugas mengelola dana nasabah berdasarkan kontrak mudharabah atau kontrak perwakilan, kedua sebagai investor yang menginvestasikan dana yang dimiliknya dan dana nasabah menggunakan alat investasi yang sesuai Syariah, ketiga sebagai penyedia jasa keuangan berdasarkan pada upah 
dalam sebuah kontrak perwakilan atau penyewaan, dan fungsi keempat adalah sebagai pengemban jasa sosial. Fungsi bank syariah sebagai manajer investasi, investor, dan penyedia jasa keuangan adalah fungsi bisnis bank syariah sedangkan, pengemban jasa sosial adalah fungsi sosial pada bank syariah.

Bank syariah selaku lembaga keuangan yang melaksanakan kegiatannya berdasarkan prinsip Syariah mengemban tanggungjawab untuk dapat melaksanakan fungsi bisnisnya dengan baik. sebagaimana disebutkan dalam Al-Quran surat Al-Mudatsir ayat 38.

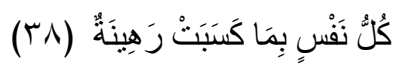

Artinya: Tiap-tiap diri bertanggung jawab atas apa yang telah diperbuatnya,(Q.S. 74: 38, Departemen Agama RI, 2012:576)

Ibnu Katsir (2005:43) menjelaskan bahwa setiap orang bergantung pada amalnyanya pada hari kiamat kelak. Demikian yang disampaikam oleh Ibnu Abbas. Di hari kiamat nanti setiap orang sebagai individu maupun entitas akan dimintai pertanggungjubjawaban atas amalan yang dikerjakan selama di dunia. Surat lain dalam Al-quran, yaitu Al-Qiyamah ayat 36 juga menjelaskan

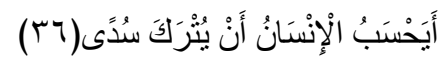

Artinya: Apakah manusia mengira, bahwa ia akan dibiarkan begitu saja (tanpa pertanggung jawaban)? (Q.S. 75: 36, Departemen Agama RI, 2012:578)

Ibnu Katsir (2005:356), setiap perbuatan di dunia akan dimintai pertanggungjawaban, bahwa kelak akan ada hari pembagkitan setelah kematian, serta menyangkal orang-orang yang mengingkarinya.

Berdasarkan pada kedua ayat tersebut maka bank syariah wajib menjalankan fungsinya dengan baik karena merupakan tanggungjawab pada seluruh stakeholder yang ada terlebih lagi tanggungjawab pada Allah SWT.

Pelaksanaan fungsi sosial Perbankan Syariah dapat dilakukan melalui dana pinjaman kebaikan (Qard), Zakat, atau dana sosial yang sesuai dengan ajaran Islam. Bank syariah juga diwajibkan berperan dalam pengembangan sumberdaya manusia dengan menyumbang dana untuk kegiatan pengembangan dan pemeliharaan lingkungan hidup. Yuliani (2012) menyebutkan bahwa untuk melihat sejauh mana tingkat kontribusi bank syariah terhadap masyarakat, dapat dilihat dari pembiayaan yang disalurkan oleh bank syariah kepada masyarakat. 
Sebagai upaya untuk dapat menjalankan fungsi bisnis dan fungsi sosialnya dengan baik maka bank syariah harus mempunyai sistem manajemen yang baik. Konsep manajemen yang baik berkaitan dengan cara mamasimalkan stakeholder value (Rivai, 2010:474). Dengan stakeholder value yang maksimal secara tidak langsung dalam jangka panjang dapat memberikan citra positif bagi perusahaan sehingga dapat menjaga kelangsungan perusahaan di masa yang akan datang. sebagai upaya dalam menerapkan manajemen yang baik maka dibuat peraturan Bank Indonesia Nomor 11/ 33/ PBI/ 2009 tentang pelaksanaan Good Corporate Governance bagi Bank Umum Syariah dan Unit Usaha Syariah serta peraturan Otoritas Jasa Keuangan (OJK) Nomor 8/ POJK.03/ 2014 tentang penilaian tingkat kesehatan Bank Umum Syariah dan Unit Usaha Syariah yang mewajibkan untuk menerapkan konsep Good Corporate Governance (GCG).

\section{LANDASAN TEORI}

Berdasarkan Undang-Undang Republik Indonesia Nomor 21 tahun 2008 tentang perbankan syariah, yang dimaksud perbankan syariah adalah segala sesuatu yang berkaitan dengan bank syariah dan unit usaha syariah, mencakup tentang kelembagaan, kegiatan usaha, serta cara dan proses dalam pelaksanaan kegiatan usaha. Dengan kata lain Bank syariah adalah bank yang menjalankan kegiatan usahanya berdasarkan prisnsip-prinsip syariah yang terdiri dari Bank Umum Syariah (BUS), Unit Usaha Syariah (UUS), Bank Pembiayaan Rakyat Syariah (BPRS).

\section{Good Corporate Governance}

Menurut Keputusan Menteri Badan Usaha Milik Negara Nomor KEP-117/M$\mathrm{MBU} / 2002$, corporate goernance adalah suatu proses dari sruktur yang digunaka organ BUMN untuk meningkatkan keberhasilan usaha dan auntabilitas perusahaan guna mewujudkan nilai pemegang saham dalam jangka panjang dengan tetap memperhatikan kepentingan stakeholder lainnya, berlandaskan peraturan perundang-undangan dan nilai-nilai etika.

Adapun menurut Pedoman Good Corporate Governance yang dikeluarkan oleh Komite Nasional Kebijakan Governance (KNKG, 2006), mendefinisikan Good Corporate Governance sebagai pilar dalamsistem ekonomi pasar yang berkaitan dengan kepercayaan terhadap perusahaan yang melaksanakan maupun terhadap iklim usaha di suatu negara untuk mendorong terciptanya iklim persaingan yang sehat dan kondusif.

Menurut Komite Nasional Kebjakan Governance (KNKG:2011), pencapaian tujuan organnisasi memerlukan sistem penataan yang teratur dan tidak berjalan sendiri-sendiri. Setiap bisnis syariah perlu memiliki empat fungsi dasar, yaitu, kepemilikan, pelaksanaan bisnis secara operasional, pengawasan, dan nasehat serta pengawasan aspek syariah, sehingga dapat tercipta check and balance dalam perusahaan. Penerapan dari empat 
fungsi dasar tersebut diantaranya melalui Rapat Umum Pemengan Saham (RUPS), Dewan Komisaris, Dewan Pengawas Syariah, Direksi dan komite-komite di bawah Dewan Komisaris dan Direksi.Terdapat tiga struktur dan dua mekanisme pengawasan sehubungan dengan penerapan GCG yang dibahas dalam penelitian ini, yaitu: (1)Dewan Komisaris, (2) komposisi dewan komisaris independen, (3)dewan pengawas syariah, (4)Frekuensi rapat dewan pengawas syariah, (5)Frekuensi rapat komite audit.

\section{Kinerja Sosial Perusahaan}

Kinerja sosial merupakan inisiatif perusahaan dalam meperhatikan keberhasilan dimensi-dimensi sosialnya, perhatian terhadap masyarakat, tatakelola perusahaan, pelanggan, karyawan, lingkungan, dan hak asasi manusia (Makni et al. 2009). Fauzi (2009) menjelaskan bahwa Corporate Social Performance (CSP) merupakan interaksi antar prinsip tanggung jawab sosial, dan proses dari responsif dan kebijakan dalam menjawab isu-isu sosial

Pada perbankan syariah tanggung jawab sosial merupakan topik yang sangat relevan untuk dibahas mengingat beberapa faktor berikut; perbankan syariah berlandaskan pada hukum Islam yang mengharuskan mereka beroperasi dengan landasan moral, etika, dan tanggung jawab sosial. Selain itu adanya prinsip atas ketaatan pada perintah Allah dan khalifah serta adanya prinsip atas kepentingan umum, terdiri dari penghindaran dari kerusakan dan kemiskinan. Berdasarkan Undang-undang No. 21 Tahun 2008 pasal 4 tentang Perbankan Syariah selain mempunyai tugas untuk menghimpun dan menyalurkan dana pada masyarakat, Bank Umum Syariah (BUS) dan Unit Usaha Syariah (UUS) dapat menjalankan fungsi sosial dalam bentuk lembaga baitul mal, yaitu dengan menerima dana yang berasal dari zakat, infaq, shodaqoh, hibah, atau dana sosial lainnya dan menyalurkan pada organisasi pengelola zakat. BUS dan UUS juga dapat menghimpun dana sosial yang berasal dari wakaf uang dan menyalurkannya kepada pengelola wakaf sesuai dengan kehendak pemberi wakaf. Selain itu bank syariah juga memiliki produk pembiayaan dana kebajikan (qard).

Pada penelitian ini penulis menggunakan tiga variabel sebagai indikator kinerja

sosial bank syariah diantaranya: (1) Pembiayaan mudharabah-musyarakah yang didapatkan dari total penjumlahan pada pembiayaan mudharabah dan musyarakah; (2) pembiayaan Qard yang didapatkan dari total pembiayaan qard yang dikeluarkan bank syariah; (3) zakat yang didapatkan dari total zakat yang disalutkan oleh bank syariah.

\section{Efisiensi}

Efisiensi merupakan sebuah indikator keberhasilan seseorang atau organisasi yang diukur dari besaran sumberdaya yang digunakan dalam menjalankan suatu kegiatan (Muhammad, 2015:262). Menurut Collin (1999:102) dalam Fitri (2016) efisiensi 
adalah kemampuan dalam bekerja atau memproduksi hasil yang tepat dengan cara yang tepat. Sedangkan Kosr dan Rosenwig dalam Sutajaya dan Lestari (2009) efisiensi diartikan sebagai rasio antara output dengan input.

Suatu perusahaan dapat dikatakan efisien jika menggunakan input yang lebih sedikit dibandingkan input yang digunakan perusahaan lain untuk menghasilkan output yang sama atau menghasilkan jumlah output yang lebih besar (Permono dan Dermawan. 2000:45). Efisiensi juga mengindikasikan seberapa baik perusahaan dalam memanfaatkan sumberdaya yang dimiliki untuk menyelesaikan suatu hasil. Sehingga efisiensi dapat dikatakan sebagai komponen produktifitas yang mengacu pada perbandingan jumlah aktual dari jumlah optimal input dan output (Kumbhakar dan Lovell, 2000).

Rasio BOPO merupakan rasio yang digunakan oleh Bank Indonesia dalam mengukur tingkat efisiensi dari suatu bank. Rasio BOPO digunakan untuk mengukur kemampuan manajemen dalam mengatur biaya operasional terhadap pendapatan operssional. Dendawijaya, (2009:121) Semakin kecil rasio BOPO mengindikasikan bahwa bank telah semakin efisien dalam mengatur biaya operasionalnya, sehingga risiko yang diterima bank akan semakin kecil serta profitabilitas akan meningkat. Hal serupa juga dikatakan oleh Riyadi $(2006 ; 159)$ bahwa, Bopo dalah rasio yang membandingkan biaya operasional terhadap pendapatan operasional, semakin rendah rasio BOPO mengindikasikan bahwa kinerja manajemen bank yang semakin baik, karena lebih efisien dalam memanfaatkan sumberdaya yang ada dalam perusahaan.

\section{Hipotesis dan Model Analisis}

Berdasarkan penjelasan latar belakang, rumusan masalah, tujuan penelitian, tinjauan pustaka, maka hipotesis dalam penelitian ini adalah :

H1 : GCG berpengaruh terhadap faktor efisiensi

H2 : GCG berpengaruh terhadap kinerja sosial

H3 : Kinerja sosial berpengaruh terhadap efisiensi.

H4: GCG berpengaruh terhadap efisiensi melalui kinerja sosial.

\section{METODE PENELITIAN}

Pendekatan dalam penelitian ini adalah pendekatan kuantitatif. Variabel laten yang digunakan berjumlah tiga variabel yaitu satu variabel eksogen (GCG); satu variabel endogen intervening (Kinerja sosial); dan satu variabel endogen (Efisiensi). Adapun definisi operasional dalam penelitian ini ditunjukkan dalam tabel 1 berikut. 
Tabel 2

Definisi Operasional

\begin{tabular}{llc}
\hline \multicolumn{1}{c}{ Variabel } & \multicolumn{1}{c}{ Indikator } & \multicolumn{1}{c}{ Sumber Data } \\
\hline $\begin{array}{l}\text { Good Corporate } \\
\text { Governance (GCG) }\end{array}$ & $\begin{array}{l}\text { Kdewan Komisaris, Komposisi } \\
\text { dewan komisaris indepependen, } \\
\text { Dewan pengawas syariah, } \\
\text { frekuensi rapat dewan } \\
\text { pengawas syariah, frekuensi } \\
\text { rapat komite audit. }\end{array}$ & $\begin{array}{c}\text { Laporan GCG tahunan pada } \\
\text { masing-masing bank umum } \\
\text { syariah }\end{array}$ \\
\hline Kinerja Sosial & $\begin{array}{l}\text { Pembiayaan Mudharabah- } \\
\text { Musyarakah, zakat, qard }\end{array}$ & $\begin{array}{l}\text { Laporan keuangan tahunan } \\
\text { pada masing-masing bannk } \\
\text { umum syariah }\end{array}$ \\
\hline Efisiensi & Rasio BOPO & $\begin{array}{c}\text { Laporan keuangan tahunan } \\
\text { pada masing-masing bannk } \\
\text { umum syariah }\end{array}$ \\
\hline
\end{tabular}

Sumber: Penulis

Jenis data yang digunakan dalam penelitian ini adalah data sekunder, berupa data yang dipublikasikan oleh masing-masing bank umum syariah pada periode 20122016 dengan menggunakan purposif sampling.

Penelitian ini menggunakan teknik analisis Partial Least Square (PLS) untuk keperluan analisis data dan menggunakan software SmartPLS 3.0 sebagai alat bantu pengolahan data. Dalam PLS terdapat dua pengevaluasian model, yaitu evaluasi model pengukuran (outer model) dan evaluasi model struktural (inner model). Salah satu keunggulan PLS adalah dapat digunakan untuk menganalisis model dengan dukungan teori lemah, sehingga dapat menggunakan analogi dari bidang ilmu lain yang paling dekat hubungannya dengan model yang diteliti.

\section{HASIL DAN PEMBAHASAN}

\section{Evaluasi Model Pengukuran}

Pada penelitian ini terdapat konstruk formatif dan reflektif. Konstruk GCG adalah konstruk formatif, sedangkan konstruk kinerja sosial adalah konstruk reflektif, dengan demikian menggunakan dua evaluasi pengujian.

Pengukuran Outer Model konstruk formatif dalam penelitian ini dievaluasi berdasarkan dengan melihat signifikansi weightnya dengan melihat $T$ Values. Nilai signifikansi weight harus melebih 1,96. Jika terdapat indikator yang tidak valid, maka indikator tersebut harus dikeluarkan dari model. 


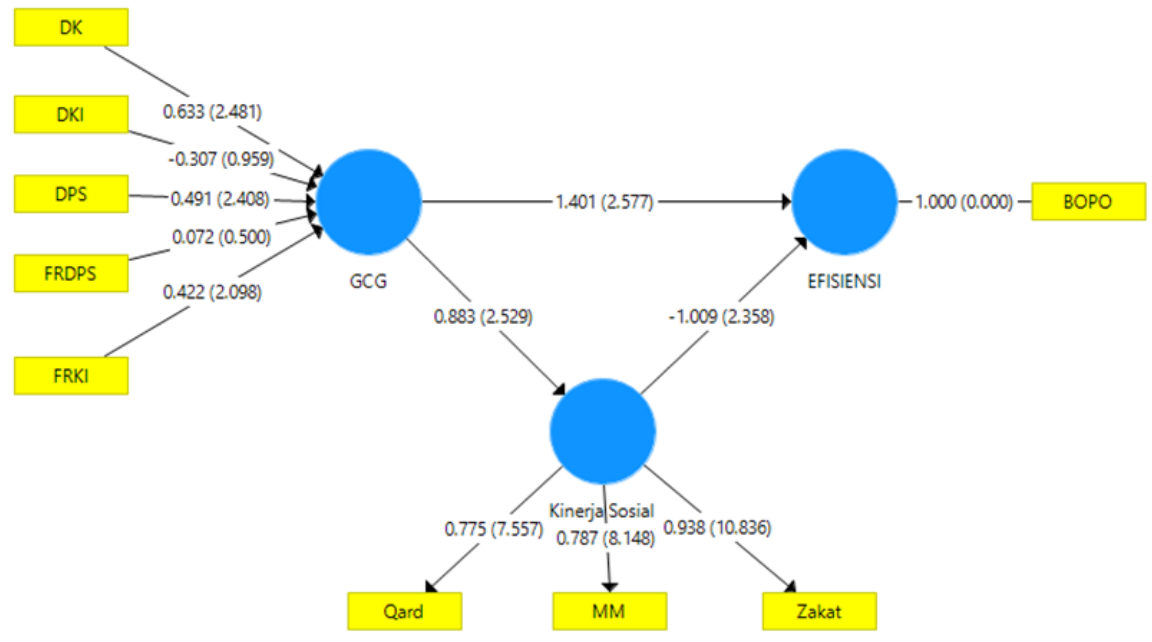

Sumber: SmartPLS 3.0

Gambar 1 Pengukuran Outer Model konstruk formatif

Dapat diketahui bahwa dari lima indikator formatif yang diuji terdapat dua indikator yang nilainya kurang dari 1,96, yaitu indikator komposisi komisaris independen (KKI) dan indikator Frekuensi Rapat Dewan Pengawas Syariah (FRDPS). Untuk mendapat model yang lebih baik, maka indikator yang tidak valid harus didrop dari model. Dengan demikian diperoleh hasil sebagai berikut:

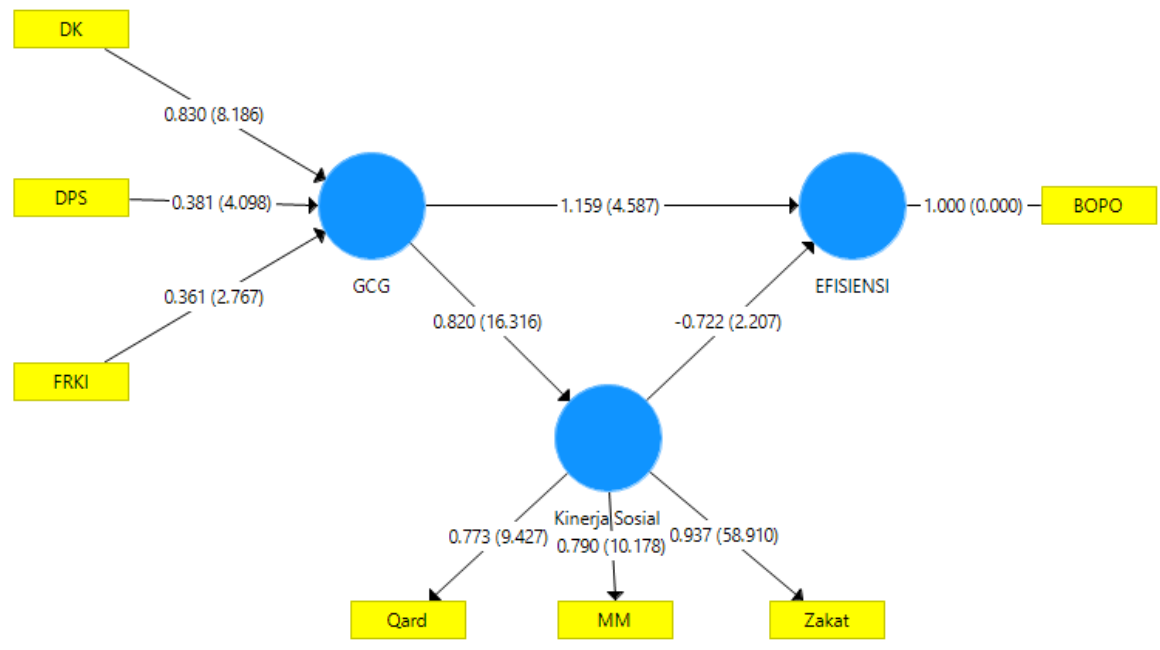

Sumber: SmartPLS 3.0

Gambar 2 Perbaikan Pengukuran Outer Model konstruk formatif

Setelah model diuji kembali dengan menghilangkan dua indikator yang tidak valid, maka didapat model yang lebih baik dengan semua indikator valid 


\section{Evaluasi Model Struktural}

Model struktural bertujuan untuk memprediksi hubungan antar variabel laten yang dihipotesiskan. Evaluasi model struktural dalam PLS dapat melihat tiga nilai berikut, yaitu R-squares, Q-squares dan uji t. Berikut ini merupakan nilai R-squares dalam model yang diolah.

Tabel 3

$R$-squares

\begin{tabular}{lc}
\hline & $\begin{array}{c}\text { Original } \\
\text { Sample (0) }\end{array}$ \\
\hline Efisiensi & 0,492 \\
\hline Kinerja sosial & 0,673 \\
\hline
\end{tabular}

Sumber: SmartPLS 3.0 (diolah)

Berdasarkan tabel 1.3 dapat dijelaskan dalam variabel kinerja sosial sebagai variabel intervening dapat dijelaskan oleh variabel GCG memiliki nilai R-square sebesar 0,673. Hal tersebut menunjukkan bahwa variabel kinerja sosial dapat dijelaskan oleh variabel GCG sebesar $67,3 \%$, dan $32,7 \%$ dijelaskan oleh variabel lain diluar variabel yang telah diteliti. Sedangkan variabel tingkat efisiensi dapat dijelaskan oleh variabel kinerja sosial memiliki nilai R-square sebesar 0,492. Hal tersebut menunjukkan bahwa variabel tingkat efisiensi dijelaskan oleh variabel kinerja sosial sebesar $49,2 \%$, dan $50,8 \%$ dijelaskan oleh variabel lain. Berdasarkan hasil tersebut dapat diasumsikan bahwa, variabel endogen intervening kinerja sosial memiliki model struktural yang kuat karena memiliki nilai R-square antara $>0,45$ memasuki $\leq 0,70$ sedangkan variabel endogen tingkat efisiensi memiliki model struktural (inner model) yang juga kuat karena R-square nya >0,45.

Untuk nilai Q-squaresdalam penelitian inididapat melalui perhitungan sebagai berikut:

$$
\begin{aligned}
& Q^{2}=1-\left[\left(1-R 1^{2}\right)\left(1-R 2^{2}\right) \ldots \ldots\left(1-\mathrm{Rp}^{2}\right)\right] \\
& Q^{2}=1-\left(\left(1-0,492^{2}\right)\left(1-0,673^{2}\right)\right) \\
& Q^{2}=1-((1-0,757936)(1-0,547071)) \\
& Q^{2}=1-0,414644805456 \\
& Q^{2}=0,585355194544
\end{aligned}
$$

Berdasarkan hasil diatas menunjukkan bahwa nilai Q-square pada model sebesar 0,585355194544. Menurut aturan dari Q-square apabila nilai Q2 > 0 maka menunjukkan model mempunyai predictive relevance sedangkan nilai Q2 $<0$ menunjukkan bahwa model kurang predictive relevance. Maka dari itu, dari nilai yang didapat oleh kedua variabel tersebut menunjukkan bahwa keduanya termasuk predictive relevance. 
Langkah selanjutnya adalah uji pengaruh antar variabel atau uji signifikansi t. Penelitian ini menggunakan tingkat signifikansi sebesar $5 \%$ dengan p-value 0,05 . Jika diperoleh $p$-value < 0,05 maka hipotesis diterima, begitupun sebaliknya. Pengujian hipotesis akan dilakukan dengan melihat hasil path coefficients yang dihasilkan melalui proses bootstraping, yang ditunjukkan pada tabel 1.4 berikut.

Tabel 4

Path Coefficient

\begin{tabular}{ccccc}
\hline & Original Sample & T Statistics & P Value & Keterangan \\
\hline GCG -> Efisiensi & 1,159 & 4,587 & 0,000 & Signifikan \\
\hline $\begin{array}{c}\text { GCG }->\text { Kinerja } \\
\text { Sosial }\end{array}$ & 0,820 & 16,316 & 0,000 & Signifikan \\
\hline $\begin{array}{c}\text { Kinerja Sosial -> } \\
\text { Efisiensi }\end{array}$ & $-0,722$ & 2,207 & 0,028 & Signifikan \\
\hline
\end{tabular}

Sumber: SmartPLS 3.0 (diolah)

Tabel 5

Total Indirect Effect

\begin{tabular}{ccccc}
\hline & $\begin{array}{c}\text { Original } \\
\text { Sample }\end{array}$ & T Statistics & P Value & Keterangan \\
\hline $\begin{array}{c}\text { GCG -> Kinerja Sosial - } \\
\text { > Efisiensi }\end{array}$ & $-0,592$ & 2,208 & 0,043 & Signifikan \\
\hline
\end{tabular}

Sumber: SmartPLS 3.0 (diolah)

Berdasarkan tabel diatas, dapoat diketahui bahwa:

1. Pengaruh GCG terhadap efisiensi memiliki P-Value $<0,05$ yaitu 0,000 , maka $H 1$ diterima. Hal tersebut berarti GCG mempengaruhi efisiensi secara signifikan sebesar 1,159 .

2. Pengaruh GCG terhadap kinerja sosial memiliki $P$-Value $<0,05$ yaitu 0,000 maka $H 2$ diterima. Hal tersebut berarti GCG mempengaruhi efisiensi secara signifikan sebesar 0,820

3. Pengaruh kinerja sosial terhadap efisiensi memiliki $\mathrm{P}$-Value $<0,05$ yaitu 0,028 maka $\mathrm{H3}$ diteriama. Hal tersebut berarti kinerja sosial mempengaruhi efisiensi secara signifikan sebesar $-0,722$.

4. Pengaruh GCG terhadap efisiensi melalui kinerja sosial memiliki P-Value $<0,05$ yaitu 0,043, maka H4 diterima. Hal tersebut menunjukkan kinerja sosial memoderasi secara signifikan sebesar $-0,592$. 


\section{PEMBAHASAN}

\section{Pengaruh Good Corporate Governance terhadap efisiensi}

Hasil analisis koefisien parameter jalur (path coeffisient) yang ditunjukkan pada tabel 4.14 menyatakan bahwa variabel GCG berpengaruh positif signifikan terhadap tingkan efisiensi yang diproksikan dengan rasio BOPO sebesar 1,159. Hal tersebut dapat dibuktikan dengan melihat nilai $T$ statistik sebesar 4,587, di mana angka tersebut melebihi 1,96 yang merupakan batas suatu variabel dikatakan memiliki hubungan signifikan. Sedangkan $p$ value variabel GCG terhadap efisiensi memiliki nilai 0,000 atau kurang dari 0,05. Nilai koefisien parameter antara GCG dan efisiensi adalah 1,159. Hal tersebut berarti jika GCG bertambah 1 satuan, maka efisiensi yang diproksikan dengan rasio BOPO akan meningkat sebesar 1,159.

GCG dalam penelitian ini diukur dengan menggunakan indikator jumlah dewan komisaris, jumlah dewan pengawas syariah, dan frekuensi rapat komite audit. Sesuai dengan hasil penelitian yang menunjukkan bahwa GCG berpengaruh positif signifikan terhadap efisiensi yang diproksikan dengan rasio BOPO. Hal tersebut berarti apabila GCG bertambah, maka nilai rasio BOPO juga akan mengalami peningkatan yang berarti bank akan semakin tidak efisien.

Dari hasil penelitian didapatkan bahwa mekanisme good corporate governance menyebabkan efisiensi semakin menurun, hal tersebut terjadi dikarenakan mekanisme good corporate governance dalam penelitian ini yang diwakilkan oleh indikator dewan komisaris dan dewan pengawas syariah merupakan bagian dari struktur kepengurusan perusahaan, sedangkan frekuensi rapat komite audit merupakan bagian dari kegiatan perusahaan. Dengan demikian apabila semakin banyak jumlah pengurus dalam suatu perusahaan hal tersebut juga akan berdampak pada beban operasional perusahaan yang semakin meningkat yang disebabkan oleh jumlah gaji yang dikeluarkan semakin besar, sedangkan Frekuensi rapat yang terlalu sering dilaksanakan juga akan menambambah beban operasional, dikarenakan perusahaan akan membiayayai setiap rapat yang diselenggarakan dan akhirnya akan menambah biaya operasional perusahaan.

Badunenko et al. (2006) dalam Dadang et al. (2015), menjelaskan bahwa determinan faktor penentu efisiensi operasional dibedakan menjadi 2 faktor, yaitu faktor internal dan eksternal. Faktor eksternal di antaranya adalah industry affiliation, location, year effects, dan market shares. Sedangkan faktor internal di antaranya adalah karakteristik perusahaan yang diproksikan dengan ukuran perusahaan dan biaya RnD, kegiatan outsourcing, dan ownership \& legal form. Subandi, (2014) dalam Dadang et al. (2015), juga menganalisis faktor-faktor yang memengaruhi efisiensi operasional bank di Indonesia yang di antaranya adalah total aset, tipe bank (status bank), rasio CAR, rasio 
LDR, rasio NPL, pengeluaran operasional (operating expense), dan Net Interest Margin (NIM).

\section{Pengaruh Good Corporate Governance terhadap Kinerja Sosial}

Hasil analisis koefisien parameter jalur (path coeffisient) yang ditunjukkan pada tabel 4.14 menyatakan bahwa menunjukkan bahwa variabel GCG berpengaruh positif signifikan terhadap kinerja sosial dengan nilai t statistik 16,316 melebihi angka 1,96 yang merupakan batas suatu variabel dikatakan signifikan. Sedangkan $\mathrm{p}$ value pada variabel GCG terhadap kinerja sosial memiliki nilai 0,000 atau kurang dari 0,05. Hal tersebut menunjukkan bahwa jika variabel GCG mengalami penambahan, maka kinerja sosial juga akan meningkat. Nilai koefisien parameter antara GCG dan kinerja sosial adalah sebesar 0,820 yang berarti setiap GCG bertambah 1 satuan, maka kinerja sosial juga akan mengalami peningkatan sebesar 0.820 .

Penerapan kinerja sosial yang baik merupakan salahsatu bentuk implementasi dari penerapan konsep Good Corporate Governance (GCG). Pada konsep GCG terdapat lima prinsip dasar yang menjadi pedoman bagi para pelaku bisnis, yaitu : (1) prinsip keterbukaan informasi (Transparency), (2) prinsip akuntabilitas (accountability), (3) Prinsip tanggung jawab (Responsibility), (4) prinsip kemandirian (Indpendency), dan (5) prinsip kesetaraan dan kewajaran (Fairness). Dari lima prinsip dasar GCG Responsibility atau prinsip tanggung jawab merupakan prinsip yang paling dekan kaitannya dengan kinerja sosial perusahaan. Bentuk tanggung jawab (Responsibility) suatu perusahaan, yaitu kepatuhan perusahaan pada peraturan-peraturan yang berlaku diantaranya kepatuhan terhadap hubungan indutrial, kepatuhan terhadap perpajakan, kepatuhan terhadap kesehatan dan keselamatan kerja, memelihara lingkungan bisnis yang kondusif bersama masyarakat sekitar. Suatu perusahaan disamping memiliki tanggungjawab kepada shareholder, juga harus memiliki tanggungjawab terhadap stakeholdersnya. Berdasarkan prinsip responsibility tersebut maka semakin baik penerapan Good Corporate Governance pada suatu perusahaan juga akan berdampak pada kinerja sosial perusahaan yang semakin baik pula.

Kinerja sosial perusahaan dalam penelitian ini yang diproksikan dengan qard, pembiayaan mudharabah-musyarakah, dan zakat memerlukan penerapan prinsipprinsip good corporate governance (tata kelola) yang baik untuk dapat memaksimalkan setiap potensi yang ada. Jumlah dewan komisaris yang merupakan bagian dari mekanisme good corporate governance dalam penelitian ini memiliki dampak terhadap kinerja sosial perusahaan, semakin banyak jumlah dewan komisaris dalam perusahaan, maka akan semakin banyak masukan serta kontribusi terhadap manajemen, sehingga akan memaksimalkan pengelolaan zakat, qard, dan pembiayaan pada bank syariah. Dewan pengawas syariah juga dapat memaksimalkan kinerja sosial pada bank syariah, 
DPS memiliki wewenang dalam mengawasi kepatuhan perusahaan terhadap prinsipprinsip syariah, seperti halnya penyaluran dana zakat, infaq, shodaqoh, qard, serta produk-produk pembiayaan bank syariah lainnya. Semakin banyak jumlah DPS maka bank akan lebih tepat sasaran dalam menyalurkan dana zakat, qard, dan pembiayaan mudharabah-musyarakah. Selanjutnya frekuensi rapat komite audit dapat meningkatkan efektifitas fungsi komite audit sehingga akan lebih bertanggungjawab terhadap perusahaan. Semakin intens rapat dilaksanakan maka akan menambah fungsi internal dan environtment controll sehingga akan meningkatkan kinerja sosial perusahaan.

Hasil dari penelitian ini sesuai dengan teori yang menjelaskan bahwa implementasi dari corporate social performance (kinerja sosial) tidak terlepas dari penerapan konsep Good Corporate Governance dalam perusahaan. Hasil penelitian ini mendukung penelitian sebelumnya yang dilakukan oleh Murwaningsari (2009) yang menyatakan bahwa terdapat hubungan positif signifikan antara GCG yang diproksikan melalui kepemilikan institusional dan manajerial terhadap kinerja sosial yang diproksikan dengan CSR. Penelitian lain yang dilakukan oleh Erlinda (2015) menyatakan hal yang sama, bahwa GCG berpengaruh positif signifikan terhadap kinerja sosial bank umum syariah.

\section{Pengaruh Kinerja Sosial terhadap Efisiensi}

Hasil analisis koefisien parameter jalur (path coeffisient) yang ditunjukkan pada tabel 4.14 menyatakan bahwa variabel kinerja sosial berpengaruh negatif signifikan terhadap efisiensi perusahaan dengan nilai $t$ statistik 2,207 melebihi nilai 1,96 yang merupakan batas minimal suatu variabel dikatakan signifikan. $p$ value pada variabel kinerja sosial terhadap efisiensi memiliki nilai 0,028 atau kurang dari 0,05. Hal tersebut menunjukkan bahwa jika variabel kinerja sosial mengalami penambahan, maka efisiensi yang di proksikan dengan rasio BOPO akan mengalami penurunan. Nilai koefisien parameter antara GCG dan kinerja sosial adalah sebesar -0,722 yang berarti setiap kinerja sosial bertambah 1 satuan, maka efisiensi yang diproksikan dengan Rasio BOPO juga akan mengalami penurunan sebesar 0.722 .

Berdasarkan pasal 4 Undang-undang Nomor 21 tahun 2008 tentang perbankan syariah, dijelaskan bahwa salah satu fungsi dari bank syariah adalah fungsi sosial, dimana fungsi tersebut merupakan sesuatu yang melekat pada bank syariah. Pembiayaan Mudharabah-Musyarakah yang merupakan indikator dalam penelitian ini disamping memiliki fungsi sosial juga terdapat fungsi bisnis, sehingga apabila pembiayaan Mudharabah-Musyarakah yang merupakan implementasi dari akad bagi hasil dilaksanakan dengan baik, maka akan menurunkan risiko kegagalan dan akan meninggkatkan pendapatan operasional pada bank syariah. Dengan meningkatnya pendapatan yang didukung oleh efektifitas dalam pengelolaan, maka bank syariah 
tersebut akan semakin efisien. Selanjutnya, penelitian yang dilakukan oleh Ekawaty (2005) mengemukakan bahwa pembiayaan Mudharabah-Musyarakah akan berpengaruh secara parsial dan simultan pada laba perbankan syariah. Rosmana (2014) juga mengungkapkan bahwa pembiayaan Mudharabah-Musyarakah memiliki hubungan positif signifikan terhadap laba bank syariah hal tersebut dibuktikan dengan nilai t-hitung sebesar 9,604.

Zakat dan qard juga merupakan instrumen yang dipakai oleh bank syariah dalam menjalankan fungsi sosialnya. Menurut Bahrul (2011) zakat merupakan bagian dari konsep tanggung jawab sosial yang akan memberikan panduan pada perusahaan untuk memperhatikan kepentingan sosial disamping kepentingan perusahaan itu sendiri. Sedangkan qard juga merupakan bentuk akad sosial yang ada pada bank syariah, dimana akad qard dimaksudkan untuk tolong menolong dan tidak ada unsur bisnis didalamnya. Rosmana (2014) dalam penelitian mengungkapkan terdapat hubungan positif signifikan antar zakat terhadap laba perusahaan. Diamana apabila perusahaan sekin besar mengeluarkan zakat, maka akan berdampak pada kenaikan laba pada perusahaan. Kineja sosial dalam penelitian ini merupakan uraian ilmiah dari surat Al-Baqarah ayat 261 :

Artinya: Perumpamaan orang yang menginfakkan hartanya di jalan Allah seperti sebutir biji yang menumbuhkan tujuh tangkai, pada setiap tangkai ada seratus biji. Allah melipatgandakan bagi siapa yang Dia kehendaki, dan Allah Mahaluas, Maha Mengetahui.

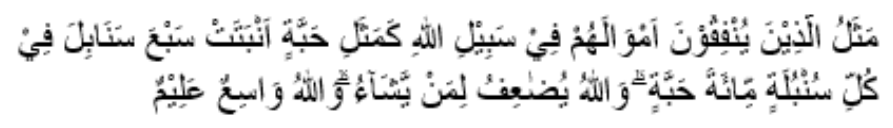

(Q.S. 02: 261, Departemen Agama RI, 2012:44)

\section{Pengaruh Good Corporate Governance terhadap Tingkat Efisiensi melalui Kinerja Sosial}

Berdasarkan pengujian terdapat hubungan pengaruh positif signifikan GCG terhadap efisiensi, akan tetapi hungan tersebut mengakibatkan apabila terjadi penambahan pada variabel GCG, maka efisiensi yang diproksikan dengan rasio BOPO akan mengalami peningkatan pula, rasio BOPO yang tinggi mengindikasikan perusahaan semakin tidak efisien. Dengan demikian variabel GCG perlu dimediasi dengan variabel lain agar mampu mengurangi rasio BOPO sehingga perusahaan dapat dikatakan lebih efisien. Untuk melihat apakah variabel kinerja sosial dapat memediasi hungan antara variabel GCG terhadap variabel efisiensi.

Berdasarkan hasil penelitian Total Indirect Effect yang ditunjukkan pada tabel 4.15 dapat diketahui nilai t statistik sebesar 2,028 melebihi nilai 1,96 yang merupakan batas minimal suatu variabel dikatakan signifikan. $p$ value pada Total Indirect Effect memiliki nilai 0,043 atau kurang dari 0,05. Besarnya pengaruh GCG terhadap efisiensi ditunjukkan dengan nilai original sample sebesar -0.592. jasil tersebut dapat di 
interpretasikan dengan setiap penambahan variabel GCG sebesar 1 satuan, maka akan menurunkan nilai efisiensi yang diproksikan dengan BOPO sebesar 0,592. Menurunnya rasio BOPO mengindikasikan perusahaan menjadi semakin efisien. Prasojo (2015) dalam penelitiannya menyatakan terdapat pengaruh negatif signifikan antara variabel GCG terhadap BOPO dengan nilai koefisien sebesar -0.266 dan tingkat signifikansi 0.006 atau $\mathrm{p}<0.05$.

Penerapan mekanisme GCG yang direfleksikan dengan jumlah dewan komisaris, jumlah dewan pengawas syariah dan frekuensi rapat komite audit akan menyebabkan perusahaan semakin tidak efisien karena dapat meningkatkan biaya operasional perusahaan. Oleh sebab itu hubungan tersebut perlu dimediasi, karena sejatinya salah satu manfaat diterapkannya Good Corporate Governance adalah untuk menjadikan perusahaan semakin efisien. Sementara itu penelitian ini menggunakan kinerja sosial sebagai mediator antara GCG terhadap efisiensi. Temuannya, kinerja sosial terbukti dapat memediasi hubungan antar GCG dan efisiensi. sehingga perusahaan dapat semakin efisien. Tatakelola yang baik dapat meningkatkan efektifitas pembiayaan mudharabah-musyarakah sehingga akan meminimalkan risiko dan memaksimalkan potensi bagi hasil yang akan berdampak pada peningkatan pendapatan operasional. Tatakelola yang baik pada pelaksanaan pembiayaan mudharabah-musyarakah, zakat dan pembiayaan qard juga secara tidak langsung dapat menambah kedekatan nasabah kepada perusahaan. Dengan terjalinnya hubungan yang baik masyarakat akan lebih merespon positif terhadap produk-produk yang ditawarkan oleh perusahaan sehingga pendapatan perusahaan akan mengalami peningkatan.

\section{SIMPULAN}

Peningkatan variabel GCG meningkatkan rasio bopo sehingga perusahaan semakin inefisien. Penambahan GCG berarti perusahaan menambah biaya operasional. Peningkatan GCG dapat meningkat kinerja sosial perusahaan hal ini dikarenakan GCG menerapkan prinsip pertanggungjawaban (responsibility) yang berdampak pada semakin efektif pengelolaan terhadap kinerja sosial. Kinerja sosial dapat meningkatkan citra perusahaan sehingga akan berpengaruh terhadap peningkatan pendapatan perusahaan yang semakin baik. Hal tersebut berarti setiap penambahan GCG dengan melalui kinerja sosial akan menurunkan tingkat efisiensi yang diproksikan dengan rasio BOPO, dengan menurunnya rasio BOPO maka perusahaan dianggap lebih efisien.

\section{DAFTAR PUSTAKA}

Antonio. (2001). Bank Syariah: Dari Teori Ke Praktik. Depok: Gema Insani dan Tazkia Cendikia

Dendawijaya, Lukman. (2001). Manajemen Perbankan. Jakarta: Ghalia Indonesia 
Fauzi, H., Mahoney, L. S., \& Abdul Rahman, A. (2009). The link between corporate social performance and financial performance: evidence from Indonesian companies.

Jafri Khalil. (2002) “Prinsip Syariah dalam Perbankan”, Jurnal Hukum Bisnis, Vol.20, Agustus-September, 2002.

Katsir, Ibnu. (2005) "Tafsir Ibnu Katsir." Bogor: Pustaka Imam Syafii.

Makni, R., Francoeur, C., \& Bellavance, F. (2009). Causality between corporate social performance and financial performance: Evidence from Canadian firms. Journal of Business Ethics, 89(3), 409.

Muljawan, dadang, et al., (2014). Faktor-Faktor Penentu Efisiensi Perbankan Indonesia Serta Dampaknya Terhadap Perhitungan Suku Bunga Kredit. Bank Indonesia

Permono, I. S. Darmawan, (2000),"Analisis Efisiensi Industri Perbankan di Indonesia (Studi Kasus Bank-bank Devisa di Indonesia Tahun 1991-1996),". Jurnal Ekonomi dan Bisnis Indonesia, 15(1), 1-13.

Prasojo. (2015). Pengaruh Penerapan Good Corporate Governance terhadap Kinerja Keuangan Bank Syariah. Jurnal Dinamika Akuntansi dan Bisnis, Vol. 2, No. 1, HIm. $59-69$

Puspasari, Rosana. (2014). Pengaruh Kinerja Sosial terhadap Profitabilitas Bank Syariah. Skripsi tidak diterbitkan. Surabaya Fakultas Ekonomi Dan Bisnis Universitas Airlangga.

Rivai dan Arifin. (2010). Islamic Baking: Sebuah Teori, konsep dan Aplikasi. Jakarta: Bumi Aksara

Riyadi, Selamet. (2006). Banking Assets and Liability Management: Edisi Ketiga. Jakarta: Lembaga Penerbitan Fakultas Ekonomi Universitas Indonesia.

S. Kumbhakar and C. A. K. Lovell. (2000) Stochastic Frontier Analysis: an Econometric Approach. Cambridge University Press, Cambridge, UK

Syarahfina, Fitri. (2017). Analisis Tingkat Efisiensi BPRS di Pulau Jawa Megggunakan Stochastic Frontier Analysis (SFA). Skripsi. Universitas Airlangga

Yuliani. (2012). Analisis Pengaruh Kinerja keuangan Terhadap Kinerja Sosial Bank Umum Syariah di Indonesia Tahun 2006-2010. Skripsi tidak diterbitkan. Depok Fakultas Ekonomi universitas Indonesia 